\title{
Advanced Oxidation Processes for Wastewater Treatment: Facts and Future Trends
}

\author{
Djamel Ghernaout ${ }^{1,2 *}$, Noureddine Elboughdiri ${ }^{1,3}$ \\ ${ }^{1}$ Chemical Engineering Department, College of Engineering, University of Ha'il, Ha'il, KSA \\ ${ }^{2}$ Chemical Engineering Department, Faculty of Engineering, University of Blida, Blida, Algeria \\ ${ }^{3}$ Département de Génie Chimique de Procédés, Laboratoire Modélisation, Analyse, et Commande des systèmes, Ecole Nationale \\ d'Ingénieurs de Gabès (ENIG), Gabès, Tunisia \\ Email: ^djamel_andalus@hotmail.com
}

How to cite this paper: Ghernaout, D. and Elboughdiri, N. (2020) Advanced Oxidation Processes for Wastewater Treatment: Facts and Future Trends. Open Access Library Journal, 7: e6139.

https://doi.org/10.4236/oalib.1106139

Received: February 5, 2020

Accepted: February 18, 2020

Published: February 21, 2020

Copyright (C) 2020 by author(s) and Open Access Library Inc.

This work is licensed under the Creative

Commons Attribution International

License (CC BY 4.0).

http://creativecommons.org/licenses/by/4.0/

\begin{abstract}
Pollution provoked by antibiotics and antibiotic-resistant bacteria must be placed as a worldwide health and ecological worry. Advanced oxidation processes (AOPs) are viewed as a greatly reasonable technique concerning water treatments for eliminating organic contaminants categorized as bio-recalcitrant and for the demobilization of pathogens, which are not touchable via traditional methods. This work discusses briefly the main recent facts and future trends in the field of applying AOPs in wastewater treatment. There is an urgent need for strengthening the studies on eliminating pollutants and microorganisms for wastewater reuse utilizing various AOPs. In-depth investigation about their reduction pathways employing AOPs is needed. Coupling AOPs with membrane processes should be kept in mind for better safety and pollutant removal.
\end{abstract}

\section{Subject Areas \\ Environmental Sciences}

\section{Keywords}

Wastewater Treatment, Advanced Oxidation Processes (AOPs), Contaminants of Emerging Concern (CECs), Antibiotic-Resistant Bacteria (ARB), Antibiotic Resistant Gene (ARG), Water Reuse

\section{Introduction}

Water is the heart of sustainable development; however, it is a restricted resource [1] [2]. Global warming gave rise to a terrifying deterioration of freshwa- 
ter resources and their accessibility, therefore causing a large dare throughout the world. As an illustration, the number of people and regions touched by water shortage augmented nearly $20 \%$ in the summer of 2017 in Europe [3]. This tendency is awaited to persist, provoking worry across the European Union (EU) and neighboring nations and generating significant ecological and economic sequels.

Immoderate water extraction for agricultural irrigation and for industrial implementations remains one of the main threats to the aquatic ecosystems in the EU; however, the supply of potable water is a crucial condition for the expansion of economic sectors that depend on water [4]. Thus, hydric resources have to be handled more efficiently [5] [6] [7]. A handy option is to implement ecologically potential treatments to wastewater to recuperate it for the following objectives. Water reuse is an approach with a small number of negative ecological effects if contrasted to desalination or water transfers and presents economic and social advantages [8] [9] [10]. These days, even if water reuse could never be solved by itself water lack problems, at least it may assist to enhance the quality and quantity of the planet's water supplies [1] [11] [12] [13].

Selecting the best treatment for recuperating wastewater is a function of its ultimate targets. As a consequence, lower cost, robust, and more efficient techniques to clean and sanitize wastewater are needed without threatening human health or stressing nature by the remediation itself. In this direction, advanced oxidation processes (AOPs) are viewed as a greatly reasonable technique concerning water treatments for eliminating organic contaminants categorized as bio-recalcitrant [14] [15] and for the demobilization of pathogens not touchable via traditional methods [16] [17] [18]. AOPs were primarily proposed for potable water treatments in 1980. In the following years, they were largely tested as oxidizing treatments implemented to various wastewaters. AOPs are described as the oxidation processes linked to the production of reactive oxygen species (ROS) like hydroxyl radicals $\left({ }^{\bullet} \mathrm{OH}\right)$ in adequate amount to generate recuperated effluents [16]. Hydroxyl radicals possess elevated redox potential $(2.8 \mathrm{eV})$ and are non-selective [1]. They are able to attack organic matter via four routes: hydrogen abstraction, integration or addition of radicals, and electron transfer [1]. Their reaction with organic pollutants produces carbon radicals $\left({ }^{\bullet} \mathrm{R}\right.$ or $\left.{ }^{\bullet} \mathrm{R}-\mathrm{HO}\right)$, which may be converted to organic peroxyl radicals (ROO) with $\mathrm{O}_{2}$. All the radicals moreover react joined by the production of additional reactive species like super oxide $\left(\mathrm{O}_{2}^{\bullet-}\right)$ and hydrogen peroxide $\left(\mathrm{H}_{2} \mathrm{O}_{2}\right)$, conducting to chemical demolition and, in some situations, the mineralization of water target contaminants [16]. If an $\mathrm{AOP}$ is utilized as tertiary treatment, ${ }^{\bullet} \mathrm{OH}$ radicals are formed in situ because of their short lifetime via various techniques, comprising a mixture of oxidizing agents $\left(\mathrm{O}_{3}\right.$ and $\left.\mathrm{H}_{2} \mathrm{O}_{2}\right)$, ultrasound (US) or irradiation (UV), and catalysts [1]. The most usual catalyst remains titanium dioxide $\left(\mathrm{TiO}_{2}\right)$. If the $\mathrm{TiO}_{2}$ particles are illuminated by UV light, they are excited and produce valence band holes where ${ }^{\circ} \mathrm{OH}$ are generated in contact with water [1]. Nevertheless, re- 
cycling and recuperating such suspended $\mathrm{TiO}_{2}$ particles become inconvenient and costly, making the employment of suspended systems not feasible. As an option, fresh setups have been presented employing such an immobilized catalyst [1]. Nevertheless, integrating hydrogen peroxide with Ultraviolet-C light (UVC) radiation leads to the most performant manner for generating ${ }^{\bullet} \mathrm{OH}$ [1]. Further, employing iron [19] species as free catalysts for forming ${ }^{\bullet} \mathrm{OH}$ in Fenton methods has been broadly investigated; however, its implementation in wastewater like tertiary treatments in actual circumstances stays limited because the optimal $\mathrm{pH}$ is 2.8 [20]. For such cause, researches have suggested three amended Fenton process: heterogeneous Fenton, photo-Fenton, and electro-Fenton [20]. With a view to produce the photo-Fenton response, the classical Fenton device is open to the UV light with the objective of enhancing the photo-reduction of dissolved ferric iron $\left(\mathrm{Fe}^{3+}\right)$ to ferrous iron species $\left(\mathrm{Fe}^{2+}\right)$ [20] [21] [22] [23]. In the electro-Fenton reaction, the two Fenton reagents can be formed with electrochemical techniques [20] [24]. Additional ${ }^{\bullet} \mathrm{OH}$ and hydrogen peroxide production setup is the water sonolysis [1]. This technique remains less tried in wastewater as the initial operational costs are too elevated, and the treated volumes are very small as compared to other processes. Not only are ${ }^{\bullet} \mathrm{OH}$ oxidant agents, but they are also sulfate radicals. Such species are highly reactive, and they possess a short life cycle. Consequently, the ${ }^{\bullet} \mathrm{OH}$ may be produced from them at alkaline conditions.

As aforesaid, ${ }^{\bullet} \mathrm{OH}$ radicals, formed throughout the implementation of AOPs on secondary effluents are apt to eliminate wastewater hazardous products and convert them into less poisonous contaminants, furnishing an option for remedying wastewater [16]. In addition to oxidation via ${ }^{\bullet} \mathrm{OH}$, other concurrent reactions may occur throughout the treatments employing AOP, giving rise to the demolition of wanted compounds in wastewater [16]. The action of such non-radical oxidative pathways in eliminating pollutants may be unimportant or controlling following the reaction circumstances and the utilized AOP kind [1].

Lately, small levels of inorganic, organic, and mineral compounds in the aquatic medium have increased observably, mostly by human activities like immoderate and fast industrialization, urban encroachment, and enhanced agricultural procedures [8]. One practical solution for removing organic contaminants from wastewater is the usage of AOPs or their integrations with additional treatments [24] [25] [26] [27]. Such techniques have been frequently categorized as being greatly able to eliminate recalcitrant contaminants or being employed as a pre-treatment to convert pollutants into shorter-chain chemicals that can be treated after via conventional biological processes [16] [28] [29]. One AOP or integration must be suitably selected for dealing with a particular industrial or domestic wastewater, taking into account parameters like wastewater properties, technical applicability, and economical considerations [1] [30] [31].

It is as well proved that municipal wastewater treatment plants (MWWTPs) constitute a significant stock of ecological water pollution. The global load of 
organic contaminants discharged by MWWTPs is a function of the number of inhabitants and the contamination received from local industries connected to the domestic sanitary system. A large set of poisonous remains (chemical or biological products) are produced every day by various sectors, which may be considered as toxic because of the likely negative influences that may induce (neurotoxicity, endocrine disruption, cancer) [1] [9]. Between the pollutants existing in WWTP effluents are personal care products, pharmaceuticals, pesticides, gasoline additives, flame retardants, drugs, plasticizers, and numerous chemicals frequently categorized as "contaminants of emerging concern (CECs)" [30] [31]. Such chemicals are detected at ng/L- $\mu$ g/L levels in MWWTP effluents; however, they stay not regulated [8]. WWTPs are seen as the principal route of entry of CECs to nature. Throughout the water treatment techniques, or once in nature, such products may as well be converted by a set of chemical, photochemical, or biological processes that conduct to the generation of transformation products (TPs), which may, at last, be more persistent or poisonous than the initial chemicals [6]. The inefficacious reduction of CECs via MWWTPs is a severe restriction for water reuse concerning the safety/sustainability of reuse usages like irrigation in agriculture or gardens and golf courses [8]. For that reason, the regulations do not authorize that the biologically treated wastewater may be directly reused since its content of health hazard micropollutants [32]. Such hazardous chemicals may be gathered in vegetables and soils with a huge effect on potable water resources and food security [33]. This status necessitates the expansion of substitutional treatment techniques to restrict the discharge of such products in nature [34]. Several publications established the efficacious reduction of micropollutants carried in real domestic wastewater [35]. Membrane bioreactor (MBR) technology merging conventional activated sludge (CAS) treatment with a membrane filtration setup was noted as an alternative to increasing the effluent quality reducing the membrane price [28]. Conversely, MBR is not a convenient technique for removing micropollutants because of membrane-fouling control [31] [36]. In this context, membrane aeration, permeability loss, and membrane replacements are parameters with elevated running costs [37] [38] [39] [40]. In order to substitute MBR technique, it may be preferred to employ solar AOPs as tertiary treatments for CECs elimination because the usage of solar energy diminishes investments costs [8] [41], conducting to wastewater treatments that are easy, robust, and inexpensive. Between the AOPs, the more investigated remains the heterogeneous photocatalysis employing $\mathrm{TiO}_{2}$ as a catalyst. Nevertheless, it was proved that it is not performant as long treatment periods are required for the complete removal of microcontaminants [8]. One more AOP that generated low microcontaminant decomposition is the solar photo-Fenton running at neutral $\mathrm{pH}[20]$. With a view to averting the iron precipitation in neutral $\mathrm{pH}$ circumstances, chelating agents are necessitated for maintaining the catalyst in solution. Usually, the complexing agents are existing in the wastewater; however, they are eliminated throughout secondary biological treatment or drinking water 
treatment stages. In fact, there is a broad variety of agents that can be so helpful for maintaining the dissolved iron in the course of the solar photo-Fenton method and to stabilize the free radical formation [1].

Wastewater effluents carry not only toxic inorganic and organic chemicals but as well pathogens. Chlorination, UV-C radiation, and ozone are processes usually utilized for killing microorganisms in WWTPs. Disinfecting wastewater mostly concentrates on particular classes of microbe comprised in the water reuse regulations for various usages, which involve total and fecal coliforms, Crystosporidium sp., or Legionella sp. [42] [43] [44] [45] [46]. Injecting chlorine products (chlorine gas, sodium hypochlorite, or calcium hypochlorite) stays the most cost-efficient remediation and has shown to be lethal against a large variety of wastewater pathogens [32] [47] [48] [49] [50]. Demobilizing bacteria is obtained through various cellular oxidation routes and inhibition of enzymatic activity together with the demolition of the cell membrane [51] [52] [53]. As related with the wastewater disinfection under UV-C radiation, it was proved that the photons were absorbed by the microorganisms' genetic material (DNA), therefore averting the cellular replication. Moreover, the aggregated UV-A energy per unit of treated water volume dose, in terms of $\mathrm{kJ} / \mathrm{L}$, is a fundamental factor to control the microorganism demobilization upon UV radiation in the function of treatment period when the system is photo-limited. However, the attention on ozone applications is growing because this compound possesses the potential to demobilize microbial cells and to diminish the charge of organic matters [1].

Actually, AOPs are established as substitutional techniques thanks to their capability to demolish a wide set of pollutants and to eliminate microbes from wastewater. Nevertheless, such processes are being studied with a view to reduce related running prices and guarantee the practicality. The leading AOPs examined for treating water remain $\mathrm{TiO}_{2}$, photocatalysis, $\mathrm{UV} / \mathrm{O}_{3}, \mathrm{UV} / \mathrm{H}_{2} \mathrm{O}_{2}$, Fenton, and photo-Fenton [20]. With a view to assess their chance, model microbes of fecal pollution are chosen because of their considerable immunity to most water disinfection techniques traditionally implemented. Among them, the most frequent are Escherichia coli [54], Cryptosporidium sp., or Bacillus sp. Such microbes are very hazardous to human beings. E. coli can hydrolyze conjugated estrogens by sulfatase and glucuronidase enzyme. Concerning protozoan microbes, Cryptosporidium is known for its resistance to chlorination methods, provoking intestinal infections in the human population. In addition, Bacillus $s p$. is a facultative anaerobic bacteria that may exist with a low quantity of dissolved oxygen. There are numerous Bacillus species present in nature-some of them possess an elevated wastewater purification capability to degrade highly concentrated organic matter in a short period, and they liberate a huge amount of enzymes that can degrade excess sludge. Nevertheless, additional species are dangerous if they appear in the treated water after secondary treatments, and tertiary processes like chlorination are not able to demobilize those [1]. 
Utilizing UV radiation integrated with $\mathrm{H}_{2} \mathrm{O}_{2}$ or $\mathrm{TiO}_{2}$ augments the performance of the demobilization method. The work pathway of pathogen demobilization via UV varies from the pathogen demobilization via $\mathrm{UV} / \mathrm{H}_{2} \mathrm{O}_{2}$. When both wastewater disinfection methods are contrasted, the treatment periods are shorter if the integrated technique is used [1]. One more sort of UV radiation is $\mathrm{UV}-\mathrm{C}$, which has been proved to be more performant than $\mathrm{UVA} / \mathrm{TiO}_{2}$ or $\mathrm{UV} /$ sono-chemical treatments as it has a huge disinfectant potential, reaching a demobilization decrease of 6-log during $10 \mathrm{~min}$ of application period. Nevertheless, the photo-reactivation of microbes happened at $72 \mathrm{~h}$ following the end of the used technique [1]. A further performant, solar driven AOP is the photo-Fenton process. If the $\mathrm{pH}$ levels are augmented, the ferrous iron solubility diminishes, conducting to its precipitation as $\mathrm{Fe}^{3+}$ hydroxides. This reality may be a problem if the photo-Fenton process is chosen for disinfecting wastewater; consequently, the existence of the plurality of the controlled microorganisms diminishes or even dies at $\mathrm{pH}<3$. With a view to handle such blockage and assess the demobilization of microbes via the photo-Fenton process, many investigations were realized at $\mathrm{pH}>4$, where microorganisms are apt to endure [20]. To demobilize microbes by photocatalysis via $\mathrm{TiO}_{2}$, a crucial truth is the internal cellular destruction generated by actions of ROS, like ${ }^{\bullet} \mathrm{OH}$, just as for photocatalysis by $\mathrm{TiO}_{2}$. Such impact on vital compounds of the cell starts with the photon absorbance via the plasmatic membrane of microbes provoking lethal physical demolition pursued by an oxidative attack by hydroxyl radicals on the cellular membranes, inducing oxidative stress and pores and forming loss of their permeability [43]. Such condition is a function of the quantity of ${ }^{\bullet} \mathrm{OH}$ and the accessibility of iron during the photocatalytic application [48].

In spite of that, present microbial pathogen identification procedures in wastewater have noted the existence of a large collection of other microorganisms. Such microbes are viewed as "emerging pathogens" with an intrinsic alarm to the population because of their manifestation in recuperated waters and discharged waters to nature. An illustration of emerging pathogens is the antibiotic-resistant bacteria (ARB) [15]. The occurrence of antibiotics in effluents has augmented in the last year [14]. Especially, municipal and hospital wastewaters are between frequent $\mathrm{ARB}$ diffusion and anthropogenic sources into the aquatic medium. Discovering a performant and advanced technique to eliminate antibiotic compounds from treated water has been the main research focus for several years. Physical manners like nanofiltration (NF) and ultrafiltration (UF) following a CAS have proved that the reduction of antibiotics augmented by up to $30 \%$ [1]; however, such methods do not eliminate microcontaminants and they only transfer them from one point to another. For such cause, the AOPs may be utilized to purify the effluent carrying pharmaceutical products as an environmentally friendly technology through employing reusable catalysts and solar light. $\mathrm{TiO}_{2}$ photocatalysis, Fenton, and photo-Fenton processes have surged as encouraging wastewater treatment technologies [20]. 
The occurrence of ARBs in the WWTP effluents released into aqueous ecosystems or reused for irrigation in agriculture shows that disinfection monotone usages do not efficiently dominate the diffusion of such pathogens into nature [15]. ARBs are commonly observed in wastewater effluents from hospitals, MWWTPs, and wastewater from cattle (known as "grey waters") [14]. Actually, the principal classical disinfection techniques are chlorination, application of ozone, and UV-C. Concerning chlorine chemicals, ARB demobilization rates are not lower than those of total heterotrophic microbes, and surprisingly the part of several ARBs may be elevated following injecting chlorine products [1].

\section{Conclusions}

From this work, the following conclusions can be drawn:

1) That being the case, the external and the internal pathways of how the chlorination method affords to augment the levels of ARB and antibiotic resistant gene (ARG) in wastewater stay not defined; thus, more investigations in this domain are necessary [14] [15]. Regarding UV-C radiation influences, the accessible data show that this technique is not performant in killing ARB and eliminating ARG upon UV-doses about $30 \mathrm{~mJ} / \mathrm{cm}^{2}$, which are frequently employed. If the $\mathrm{mJ} / \mathrm{cm}^{2}$ is elevated, the microbe demobilization rate is elevated too, therefore attaining the total log removal. Following some researches, demobilization of 4 - $5 \log$ of cell ARB needs low UV-doses from $10-20 \mathrm{~mJ} / \mathrm{cm}^{2}$ comparatively with those necessitated for removing ARG (UV-doses from 200 to 400 $\left.\mathrm{mJ} / \mathrm{cm}^{2}\right)$. This shows that chlorination and UV techniques may not result in a significant effect over levels of ARB and ARG in wastewater, even if the mechanisms of removing such biological products are not evident. In addition, the impact of ozonation on ARB has been assessed in a few studies. They noted that such a technique is not practicable for killing ARB or eliminating ARG. None the less, different technologies are being examined with a view to ameliorate the performance of wastewater disinfection and to beat many disadvantages of the aforesaid traditional techniques, diminishing the related working costs as well. AOPs driven under solar light like Fenton and photo-Fenton processes have been estimated on wastewater for demobilizing ARB and ARG. The findings found in such researches established its lethal potential on natural ARB from MWWTPs secondary effluents. On the contrary, and following the kind of resistant gene, its performance is smaller if the ARG levels are analyzed, reaching total destruction in some controlled AG [1]. The existence and the expansion of resistant microorganisms in the effluents from MWWTPs disposed into reused effluents are some of the greatest dangers to humanity linked with the domestic usage of wastewater. These realities divulge the inefficiency of classical wastewater treatments and disinfection methods for dominating the diffusion of pathogens and microbial resistance into nature. For the time being, even if some investigations are being performed to monitor the expansion of ARB and ARG in nature, the biological processes to efficiently demobilize such microbes stay va- 
gue.

2) The present investigations in wastewater treatments using AOPs are mostly concentrated at a pilot-scale in batch mode. Estimating in practical circumstances and in continuous flow mode is required for large-scale application [1].

3) Strengthening the studies on eliminating CECs and bacterial demobilization for wastewater reuse utilizing various AOPs [1].

4) Pollution provoked by antibiotics and ARBs/ARGs must be placed as a worldwide health and ecological worry. In-depth investigation about reduction pathways of antibiotics and ARBs/ARGs employing AOPs is needed [1].

5) Coupling AOPs with membrane processes should be kept in mind for better safety and pollutants removal.

\section{Conflicts of Interest}

The authors declare no conflicts of interest regarding the publication of this paper.

\section{References}

[1] Garrido-Cardenas, J.A., Esteban-García, B., Agüera, A., Sánchez-Pérez, J.A. and Manzano-Agugliaro, F. (2020) Wastewater Treatment by Advanced Oxidationprocess and Their Worldwide Research Trends. International Journal of Environmental Research and Public Health, 17, 170. https://doi.org/10.3390/ijerph17010170

[2] Ghernaout, D., Ghernaout, B. and Naceur, M.W. (2011) Embodying the Chemical Water Treatment in the Green Chemistry-A Review. Desalination, 271, 1-10. https://doi.org/10.1016/j.desal.2011.01.032

[3] European Commission (EC) (2018) Water Scarcity \& Droughts. https://ec.europa.eu/environment/water/quantity/about.htm

[4] Ghernaout, D., Elboughdiri, N. and Alghamdi, A. (2019) Direct Potable Reuse: The Singapore NEWater Project as a Role Model. Open Access Library Journal, 6, e5980. https://doi.org/10.4236/oalib.1105980

[5] Ghernaout, D. and Ghernaout, B. (2012) On the Concept of the Future Drinking Water Treatment Plant: Algae Harvesting from the Algal Biomass for Biodiesel Production-A Review. Desalination and Water Treatment, 49, 1-18. https://doi.org/10.1080/19443994.2012.708191

[6] Ghernaout, D. and Elboughdiri N. (2019) Upgrading Wastewater Treatment Plant to Obtain Drinking Water. Open Access Library Journal, 6, e5959.

https://doi.org/10.4236/oalib.1105959

[7] Ghernaout, D. (2017) Environmental Principles in the Holy Koran and the Sayings of the Prophet Muhammad. American Journal of Environmental Protection, 6, 75-79. https://doi.org/10.11648/j.ajep.20170603.13

[8] Ghernaout, D. and Elboughdiri, N. (2019) Water Reuse: Emerging Contaminants Elimination-Progress and Trends. Open Access Library Journal, 6, e5981. https://doi.org/10.4236/oalib.1105981

[9] Ghernaout, D. (2018) Increasing Trends towards Drinking Water Reclamation from Treated Wastewater. World Journal of Applied Chemistry, 3, 1-9. https://doi.org/10.11648/j.wjac.20180301.11

[10] Ghernaout, D., Alshammari, Y., Alghamdi, A., Aichouni, M., Touahmia, M. and Ait 
Messaoudene, N. (2018) Water Reuse: Extenuating Membrane Fouling in Membrane Processes. International Journal of Environmental Chemistry, 2, 1-12. https://doi.org/10.11648/j.ajche.20180602.12

[11] Ghernaout, D. (2017) Water Reuse (WR): The Ultimate and Vital Solution for Water Supply Issues. International Journal of Sustainable Development Research, 3, 36-46. https://doi.org/10.11648/j.ijsdr.20170304.12

[12] Ghernaout, D., Elboughdiri, N. and Al Arni, S. (2019) Water Reuse (WR): Dares, Restrictions, and Trends. Applied Engineering, 3, 159-170.

[13] Ghernaout, D., Elboughdiri, N. and Ghareba, S. (2019) Drinking Water Reuse: One-Step Closer to Overpassing the "Yuck Factor". Open Access Library Journal, 6, e5895. https://doi.org/10.4236/oalib.1105895

[14] Ghernaout, D. and Elboughdiri, N. (2020) Antibiotics Resistance in Water Mediums: Background, Facts, and Trends. Applied Engineering, 4, 1-6. https://doi.org/10.4236/oalib.1106003

[15] Ghernaout, D. and Elboughdiri, N. (2020) Removing Antibiotic-Resistant Bacteria (ARB) Carrying Genes (ARGs): Challenges and Future Trends. Open Access Library Journal, 7, e6003. https://doi.org/10.4236/oalib.1106003

[16] Ghernaout, D. (2013) Advanced Oxidation Phenomena in Electrocoagulation Process: A Myth or a Reality? Desalination and Water Treatment, 51, 7536-7554. https://doi.org/10.1080/19443994.2013.792520

[17] Ghernaout, D. (2019) Virus Removal by Electrocoagulation and Electrooxidation: New Findings and Future Trends. Journal of Environmental Science and Allied Research, 2019, 85-90. https://doi.org/10.29199/2637-7063/ESAR-202024

[18] Ghernaout, D. (2019) Electrocoagulation and Electrooxidation for Disinfecting Water: New Breakthroughs and Implied Mechanisms. Applied Engineering, 3, 125-133.

[19] Ghernaout, D. (2017) The Holy Koran Revelation: Iron Is a "Sent Down" Metal. American Journal of Environmental Protection, 6, 101-104. https://doi.org/10.11648/j.ajep.20170604.14

[20] Ghernaout, D., Elboughdiri, N. and Ghareba, S. (2020) Fenton Technology for Wastewater Treatment: Dares and Trends. Open Access Library Journal, 7, e6045. https://doi.org/10.4236/oalib.1106045

[21] Ghernaout, D. and Naceur, M.W. (2011) Ferrate(VI): In Situ Generation and Water Treatment-A Review. Desalination and Water Treatment, 30, 319-332. https://doi.org/10.5004/dwt.2011.2217

[22] Ghernaout, D. and Elboughdiri, N. (2019) Mechanistic Insight into Disinfection Using Ferrate(VI). Open Access Library Journal, 6, e5946. https://doi.org/10.4236/oalib.1105946

[23] Ghernaout, D. and Elboughdiri, N. (2019) Water Disinfection: Ferrate(VI) as the Greenest Chemical-A Review. Applied Engineering, 3, 171-180.

[24] Ghernaout, D. and Elboughdiri, N. (2020) Electrochemical Technology for Wastewater Treatment: Dares and Trends. Open Access Library Journal, 7, e6020.

[25] Ghernaout, D., Naceur, M.W. and Ghernaout, B. (2011) A Review of Electrocoagulation as a Promising Coagulation Process for Improved Organic and Inorganic Matters Removal by Electrophoresis and Electroflotation. Desalination and Water Treatment, 28, 287-320. https://doi.org/10.5004/dwt.2011.1493

[26] Ghernaout, D., Irki, S. and Boucherit, A. (2014) Removal of $\mathrm{Cu}^{2+}$ and $\mathrm{Cd}^{2+}$, and Humic Acid and Phenol by Electrocoagulation Using Iron Electrodes. Desalination 
and Water Treatment, 52, 3256-3270.

https://doi.org/10.1080/19443994.2013.852484

[27] Ghernaout, D. (2014) The Hydrophilic/Hydrophobic Ratio vs. Dissolved Organics Removal by Coagulation-A Review. Journal of King Saud University-Science, 26, 169-180. https://doi.org/10.1016/j.jksus.2013.09.005

[28] Ghernaout, D. (2019) Reviviscence of Biological Wastewater Treatment-A Review. Applied Engineering, 3, 46-55.

[29] Ghernaout, D. (2013) The Best Available Technology of Water/Wastewater Treatment and Seawater Desalination: Simulation of the Open Sky Seawater Distillation. Green and Sustainable Chemistry, 3, 68-88. https://doi.org/10.4236/gsc.2013.32012

[30] Ghernaout, D., Alshammari, Y. and Alghamdi, A. (2018) Improving Energetically Operational Procedures in Wastewater Treatment Plants. International Journal of Advanced and Applied Sciences, 5, 64-72. https://doi.org/10.21833/ijaas.2018.09.010

[31] Al Arni, S., Amous, J. and Ghernaout, D. (2019) On the Perspective of Applying of a New Method for Wastewater Treatment Technology: Modification of the Third Traditional Stage with Two Units, One by Cultivating Microalgae and Another by Solar Vaporization. International Journal of Environmental Sciences \& Natural Resources, 16, Article ID: 555934. https://doi.org/10.19080/IJESNR.2019.16.555934

[32] Ghernaout, D. and Elboughdiri, N. (2020) Is Not It Time to Stop Using Chlorine for Treating Water? Open Access Library Journal, 7, e6007.

[33] Ghernaout, D. (2019) Disinfection via Electrocoagulation Process: Implied Mechanisms and Future Tendencies. EC Microbiology, 15, 79-90.

[34] Ghernaout, D. and Elboughdiri, N. (2019) Iron Electrocoagulation Process for Disinfecting Water-A Review. Applied Engineering, 3, 154-158.

[35] Ghernaout, D. and Elboughdiri, N. (2019) Electrocoagulation Process Intensification for Disinfecting Water-A Review. Applied Engineering, 3, 140-147.

[36] Ait Messaoudene, N., Naceur, M.W., Ghernaout, D., Alghamdi, A. and Aichouni, M. (2018) On the Validation Perspectives of the Proposed Novel Dimensionless Fouling Index. International Journal of Advanced and Applied Sciences, 5, 116-122. https://doi.org/10.21833/ijaas.2018.07.014

[37] Ghernaout, D. (2019) Brine Recycling: Towards Membrane Processes as the Best Available Technology. Applied Engineering, 3, 71-84.

[38] Ghernaout, D. and El-Wakil, A. (2017) Requiring Reverse Osmosis Membranes Modifications-An Overview. American Journal of Chemical Engineering, 5, 81-88. https://doi.org/10.11648/j.ajche.20170504.15

[39] Ghernaout, D. (2017) Reverse Osmosis Process Membranes Modeling-A Historical Overview. Journal of Civil, Construction and Environmental Engineering, 2, 112-122.

[40] Ghernaout, D., El-Wakil, A., Alghamdi, A., Elboughdiri, N. and Mahjoubi, A. (2018) Membrane Post-Synthesis Modifications and How It Came about. International Journal of Advanced and Applied Sciences, 5, 60-64. https://doi.org/10.21833/ijaas.2018.02.010

[41] Ghernaout, D., Alghamdi, A., Touahmia, M., Aichouni, M. and Ait Messaoudene, N. (2018) Nanotechnology Phenomena in the Light of the Solar Energy. Journal of Energy, Environmental \& Chemical Engineering, 3, 1-8. https://doi.org/10.11648/j.jeece.20180301.11

[42] Boucherit, A., Moulay, S., Ghernaout, D., Al-Ghonamy, A.I., Ghernaout, B., Naceur, M.W., Ait Messaoudene, N., Aichouni, M., Mahjoubi, A.A. and Elboughdiri, N.A. 
(2015) New Trends in Disinfection By-Products Formation upon Water Treatment. Journal of Research \& Developments in Chemistry, 2015, Article ID: 628833. https://doi.org/10.5171/2015.628833

[43] Ghernaout, D. (2017) Microorganisms' Electrochemical Disinfection Phenomena. EC Microbiology, 9, 160-169.

[44] Ghernaout, D. (2018) Disinfection and DBPs Removal in Drinking Water Treatment: A Perspective for a Green Technology. International Journal of Advanced and Applied Sciences, 5, 108-117. https://doi.org/10.21833/ijaas.2018.02.018

[45] Ghernaout, D., Touahmia, M. and Aichouni, M. (2019) Disinfecting Water: Electrocoagulation as an Efficient Process. Applied Engineering, 3, 1-12.

[46] Ghernaout, D., Aichouni, M. and Touahmia, M. (2019) Mechanistic Insight into Disinfection by Electrocoagulation-A Review. Desalination and Water Treatment, 141, 68-81. https://doi.org/10.5004/dwt.2019.23457

[47] Ghernaout, D., Alghamdi, A., Aichouni, M. and Touahmia, M. (2018) The Lethal Water Tri-Therapy: Chlorine, Alum, and Polyelectrolyte. World Journal of Applied Chemistry, 3, 65-71. https://doi.org/10.11648/j.wjac.20180302.14

[48] Ghernaout, D., Alghamdi, A. and Ghernaout, B. (2019) Microorganisms' Killing: Chemical Disinfection vs. Electrodisinfection. Applied Engineering, 3, 13-19.

[49] Ghernaout, D. (2019) Greening Electrocoagulation Process for Disinfecting Water. Applied Engineering, 3, 27-31.

[50] Ghernaout, D. and Ghernaout, B. (2010) From Chemical Disinfection to Electrodisinfection: The Obligatory Itinerary? Desalination and Water Treatment, 16, 156-175. https://doi.org/10.5004/dwt.2010.1085

[51] Ghernaout, D., Naceur, M.W. and Aouabed, A. (2011) On the Dependence of Chlorine By-Products Generated Species Formation of the Electrode Material and Applied Charge during Electrochemical Water Treatment. Desalination, 270, 9-22. https://doi.org/10.1016/j.desal.2011.01.010

[52] Ghernaout, D., Moulay, S., Ait Messaoudene, N., Aichouni, M., Naceur, M.W. and Boucherit, A. (2014) Coagulation and Chlorination of NOM and Algae in Water Treatment: A Review. International Journal of Environmental Monitoring and Analysis, 2, 23-34. https://doi.org/10.11648/j.ijema.s.2014020601.14

[53] Ghernaout, D. (2017) Water Treatment Chlorination: An Updated Mechanistic Insight Review. Chemistry Research Journal, 2, 125-138.

[54] Ghernaout, D., Badis, A., Ghernaout, B. and Kellil, A. (2008) Application of Electrocoagulation in Escherichia coli Culture and Two Surface Waters. Desalination, 219, 118-125. https://doi.org/10.1016/j.desal.2007.05.010 